\title{
Anadara granosa shell powder improves the metabolism, testosterone level, and sound frequency of Pelung chickens
}

\author{
Rizki Fitrawan Yuneldi1 (iD, Pudji Astuti² ${ }^{\text {(D) }}$, Hendry T. S. Saragih ${ }^{3}$ (D) and Claude Mona Airin² (D)
}

1. Veterinary Science Postgraduate Study Program, Faculty of Veterinary Medicine, Universitas Gadjah Mada, Yogyakarta, Indonesia; 2. Department of Physiology, Faculty of Veterinary Medicine, Universitas Gadjah Mada, Yogyakarta, Indonesia;

3. Laboratory of Animal Development Structure, Faculty of Biology, Universitas Gadjah Mada, Yogyakarta, Indonesia.

Corresponding author: Claude Mona Airin, e-mail: monaairin@ugm.ac.id

Co-authors: RFY: rizkifitrawan@mail.ugm.ac.id, PA: pastuti2@ugm.ac.id, HTSS: saragihendry@ugm.ac.id

Received: 15-01-2021, Accepted: 29-04-2021, Published online: 18-06-2021

doi: www.doi.org/10.14202/vetworld.2021.1564-1571 How to cite this article: Yuneldi RF, Astuti P, Saragih HTS, Airin CM (2021) Anadara granosa shell powder improves the metabolism, testosterone level, and sound frequency of Pelung chickens, Veterinary World, 14(6): 1564-1571.

\begin{abstract}
Background and Aim: Pelung chickens make unique, pleasant, and rhythmic sounds in addition to having strong muscle mass. Performance is controlled by testosterone. A natural aromatase blocker is an agent capable of blocking the aromatase enzyme, which consequently prevents testosterone from being changed into estradiol. Such a condition results in consistently high testosterone levels. The aim of this study was to determine the effect of the administration of the shell powder of Anadara granosa on the testosterone level, frequency and quality of sounds, and metabolism of Pelung chickens within set parameters of thyroid hormone levels, the triiodothyronine $\left(\mathrm{T}_{3}\right)$ /thyroxine $\left(\mathrm{T}_{4}\right)$ ratio, and weight gain.

Materials and Methods: This study used four Pelung chickens aged 14 months. Control data consisted of data before treatment (day 0). Shell powder of $A$. granosa was administered for 56 days. Body weight (BW) was measured, and blood samples were drawn. In addition, the sounds from Pelung chickens were recorded once every 2 weeks on days $14,28,42$, and 56. The blood samples were analyzed using the enzyme immunoassay method to determine testosterone, $\mathrm{T}_{3}$, and $\mathrm{T}_{4}$ levels. The sounds of Pelung chickens were recorded using the Hagemon touch method and analyzed using the Audacity application.
\end{abstract}

Results: The results showed a significant difference $(\mathrm{p}<0.05)$ in the levels of testosterone, BW, and sound frequency after the administration of $A$. granosa shell powder, but the administration did not have a significant effect on the levels of $\mathrm{T}_{4}$ and $\mathrm{T}_{3}$ hormones (thyroid hormone), $\mathrm{T}_{3} / \mathrm{T}_{4}$ ratio, or sound duration. The testosterone content and BW of Pelung chickens increased from day 14 to day 56 , whereas $\mathrm{T}_{3}$ was indicative of the same profile as the $\mathrm{T}_{4}$ hormone. However, $\mathrm{T}_{3}$ and $\mathrm{T}_{4}$ levels and the $\mathrm{T}_{3} / \mathrm{T}_{4}$ ratio decreased and increased, respectively. The sound frequency of Pelung chickens increased from day 0 to day 14 , although sound duration decreased.

Conclusion: The administration of $A$. granosa shell powder at $0.9 \mathrm{mg} / \mathrm{kg} \mathrm{BW}$ orally could improve the metabolism, testosterone level, BW, and sound frequency of Pelung chickens.

Keywords: natural aromatase blocker, Pelung, sound, testosterone, thyroid hormone.

\section{Introduction}

Pelung chickens are endemic to Cianjur, Indonesia. The chickens are well known abroad and have high economic value. Decree Nomor 2918/kpts/ OT.140/6/2011 issued by the Ministry of Agriculture officially [1] declared Pelung as an indigenous chicken breed of Indonesia that requires protection and conservation. Pelung chickens are threatened because of their reduced population sizes [2]. Pelung chickens have a distinctive, pleasant, long, rhythmic crow, and it has been shown that the longer and the more melodious the sound, the better Pelung chickens perform $[2,3]$. Another characteristic of the chicken is the

Copyright: Yuneldi, et al. Open Access. This article is distributed under the terms of the Creative Commons Attribution 4.0 International License (http://creativecommons.org/licenses/ by/4.0/), which permits unrestricted use, distribution, and reproduction in any medium, provided you give appropriate credit to the original author(s) and the source, provide a link to the Creative Commons license, and indicate if changes were made. The Creative Commons Public Domain Dedication waiver (http:// creativecommons.org/publicdomain/zero/1.0/) applies to the data made available in this article, unless otherwise stated. increased mass and strength of their muscles [4]. The performance of Pelung chickens is controlled by testosterone, and good performance is highly important in improving the quality of the cocks. The aromatase enzyme can change the testosterone in chickens into estradiol, and consequently, high testosterone levels cannot be maintained [5].

At present, Pelung chickens grow relatively fast and show good performance, with the males cross-breeding with other free-range chickens, thereby improving the genetics of the chickens. According to Sopian et al. [6], the cross-breeding of Pelung chickens that have a far kinship with other free-range chickens and free-range chickens will theoretically provide the offspring with better performance. The thyroid gland produces thyroxine $\left(\mathrm{T}_{4}\right)$ and triiodothyronine $\left(\mathrm{T}_{3}\right)$ hormones. According to Mullur et al. [7], the thyroid hormone serves an important function in basal metabolic regulation and thermogenesis stimulation, whereas under normal conditions, the hormone can control metabolic rate and energy balance. The 
decrease in thyroid activity correlates to the decrease in metabolic regulation. A total of $99 \%$ of the thyroid hormone circulating in blood is bound to plasma proteins, such as globulin and transthyretin. The thyroid and testosterone hormones are the most significant in interaction with zinc $(\mathrm{Zn})$. Low $\mathrm{Zn}$ values in hypothyroidism and high $\mathrm{Zn}$ value in hyperthyroidism are indicative of the correlation between the $\mathrm{Zn}$ and the thyroid hormone [8]. Dittrich et al. [9] showed that the induction of testosterone in female robins correlated to the cellular differentiation process in the high vocal center. Direct injection of testosterone can prevent a decrease in testosterone levels. However, the direct injection of testosterone results in a downregulation mechanism, which causes a drastic decrease in testosterone content [10]. The administration of synthetic aromatase blocker results in the same outcome. The administration of aromatase blocker letrozole $(\mathrm{lz} ; 1.5 \mathrm{mg} / \mathrm{kg})$ can increase testosterone content and improve the reproduction performance of cocks after their peak age [11]. The supplementation of $\mathrm{Zn}$ at doses of $2.5-3 \mathrm{mg} / \mathrm{kg} /$ day for 6 weeks and weight exercise 4 times a week can significantly increase free and total testosterone content and positively impact human physical performance [5]. The administration of aromatase blocker Taxadrol can increase testosterone content [12].

Shells of Anadara granosa are usually disposed off and not used for any purpose [13]. According to Astuti et al. [14], the powder from shells of $A$. granosa contains $\mathrm{Zn}$, magnesium $(\mathrm{Mg})$, calcium, sodium $(\mathrm{Na})$, iron $(\mathrm{Fe})$, and potassium $(\mathrm{K})$. The powder from the shells A. granosa also contains copper $(\mathrm{Cu})$ and selenium (Se) [15]. Sahin et al. [16] suggested that a combination of $\mathrm{Mg}, \mathrm{Zn}$, and Se is more effective than the individual minerals in increasing testosterone levels and muscle mass. According to Astuti et al. [14], the $\mathrm{Zn}$ contained in the powder of $A$. granosa shells could play an important role as an aromatase blocker, which subsequently results in the absence of changes of testosterone into estrogen, such that blood testosterone content is consistently high. Some studies have shown that $\mathrm{Zn}, \mathrm{Mg}$, and vitamins in shellfish can increase testosterone content [5]. Supplementation with $\mathrm{Zn}$ can increase testosterone content in male rats [17]. It serves the function of an aromatase blocker that can decrease testosterone synthesis into estrogen $[14,18]$. Some studies have shown that $\mathrm{Zn}$ plays an important role in DNA synthesis, cell proliferation, immunocompetence, and maintaining nucleic and membrane integrity in which chromatin is considered to have the highest $\mathrm{Zn}$ concentration [19]. Consequently, it is necessary to determine methods to improve the performance of Pelung chickens.

The aim of this study was to determine the effects of A. granosa shell powder on body weight (BW), frequency and quality of sounds, thyroid hormone content representing one of the metabolic indicators, and testosterone hormone levels as an indicator of the performance of Pelung chickens.

\section{Materials and Methods}

\section{Ethical approval}

The study protocol was approved by Integrated Testing and Research, Universitas Gadjah Mada (UGM), (00020/04/LPPT/V/2020).

\section{Study period and location}

The study was conducted from April to December 2020 in the Department of Physiology, Faculty of Veterinary Medicine, Universitas Gadjah Mada, and the poultry farming in Bantul, Yogyakarta, Indonesia.

\section{Preparation of $\boldsymbol{A}$. granosa shell powder}

A. granosa is sourced from the north coast of Semarang and identified by Head of the Animal Systematics Laboratory, Faculty of Biology, UGM, namely, Dr. Dra. Rr. Upiek Ngesti W. Astuti, DAP., M.Kes.

A. granosa shell powder was prepared by first boiling the shells and then separating the meat from the shells, and subsequently, the shells were cleaned and dried under sunlight for 1-2 days. Next, the dried shells were boiled in $\mathrm{NaOH}(1.0 \mathrm{~N})$ solution at $50^{\circ} \mathrm{C}$ for $3 \mathrm{~h}$ and rinsed in flowing water. Subsequently, the shells were dried using an oven at $120^{\circ} \mathrm{C}$ for 6-8 $\mathrm{h}$. Once they were dry, they were pressed into powder [14].

\section{Animals and treatment}

The study used four male Pelung cocks at 14 months of age to observe the profiles of $\mathrm{T}_{3}, \mathrm{~T}_{4}$, testosterone, BW, sound frequency, and sound quality. Pelung chickens were analyzed for 7 days. Blood samples were drawn before administering A. granosa shell powder (day 0 ). Day 8 was considered the $1^{\text {st }}$ day shell powder was mixed into feed, which continued for 48 days at a dose of $0.9 \mathrm{mg} / \mathrm{kg} \mathrm{BW}$, as modified by Astuti et al. [14]. The blood sampling and voice recording were conducted once every 2 weeks on days 14, 28, 42, and 56 .

\section{Voice acoustic analysis}

The sound of Pelung chickens was recorded once every 2 weeks using the Hagemon touch method for 60 min from 7:00 to 8:00 West Indonesia time [20]. The data obtained were analyzed using the Audacity application to determine the sound frequency and quality of Pelung chickens [2]. The voice quantity test was based on the number of voices every $10 \mathrm{~min}$ (frequency), whereas the quality of the voice was based on the duration of the sound of Pelung chickens [20].

\section{Testosterone analysis}

Preparation of the wash buffer

The wash buffer used in the study was created by $20 \times$ liquefaction of $25 \mathrm{~mL}$ wash buffer solution and $475 \mathrm{~mL}$ distilled or deionized water. The resulting solution was kept at the temperature of $18-26^{\circ} \mathrm{C}$ before it was used. 


\section{Analytical procedure}

The analysis was conducted according to the manufacturer's instructions in the KITs. First, $50 \mu \mathrm{L}$ standard solution and samples were poured into wells, and $100 \mu \mathrm{L}$ enzyme conjugate reagent was added and incubated for $60 \mathrm{~min}$. Next, the wells were rinsed 3 times using $300 \mu \mathrm{L}$ wash buffer. Subsequently, 100-300 $\mu \mathrm{L}$ TMB substrate reagent was added to the wells, and the microplate was covered and incubated for $30 \mathrm{~min}$. Then, $50 \mu \mathrm{L}$ stop solution was added to the wells, and absorbance was read using an ELISA or microplate reader (ZENIX-320) at the absorbance of $450 \mathrm{~nm}$ for $15 \mathrm{~min}$.

\section{$\mathbf{T}_{3}$ and $\mathbf{T}_{4}$ analysis}

Preparation of conjugate enzyme

The conjugate enzyme consisted of the $T_{4}$ enzyme conjugate and assay diluent at the ratio of $1: 11$. The study used all of the plates such that there were 700 microns $\mathrm{T}_{4}$ enzyme conjugate in $0.7 \mathrm{~mL}$ assay diluents. Once the conjugate solution has been prepared, it was not stored for more than $24 \mathrm{~h}$.

\section{Analytical procedure}

The analysis was conducted according to the manufacturer's instructions in the KITs. First, $50 \mu \mathrm{L}$ of the standard solution and sample was poured into wells, and $100 \mu \mathrm{L}$ enzyme conjugate reagent was added. Next, $50 \mu \mathrm{L}$ biotin reagent was poured into the wells and incubated for $30 \mathrm{~min}$. Subsequently, the wells were rinsed 3 times using $300 \mu \mathrm{L}$ deionized water. Then, $100 \mu \mathrm{L}$ TMB substrate reagent was added to the wells, and the microplates were covered and incubated for $30 \mathrm{~min}$. Finally, $50 \mu \mathrm{L}$ of stop solution was added to the wells, and absorbance was read using ELISA or microplate reader (ZENIX-320) at the absorbance of $450 \mathrm{~nm}$ for $15 \mathrm{~min}$.

\section{Statistical analysis}

The results of the readings from the ELISA reader were in the form of optical density (OD) and were processed using Microsoft Excel software such that they could be applied to testosterone concentration $(\mathrm{ng} / \mathrm{mL})$ [21]. The testosterone, $\mathrm{T}_{3}, \mathrm{~T}_{4} \mathrm{BW}$, sound frequency, and sound quality values were statistically analyzed using an analysis of variance at the confidence level of $95 \%(\alpha=0.05)$. If there was a significant difference among them, the Duncan test was then conducted for pairwise comparisons. The analysis was conducted using SPSS software, version 15 [22].

\section{Results}

\section{Thyroid hormone}

The $\mathrm{T}_{3}$ and $\mathrm{T}_{4}$ contents were examined using a competitive EIA method capable of converting the OD value into content with a standard curve and the formulas $\mathrm{y}=-0.756 \ln (\mathrm{x})+2.5957$ for the $\mathrm{T}_{3}$ standard and $\mathrm{y}=-0.546 \ln (\mathrm{x})+1.457$ for the $\mathrm{T}_{4}$ standard. The standard curve of the two hormones is presented in Figure-1. The results showed that the peroral administration of $A$. granosa shell powder at the dose of $0.9 \mathrm{mg} / \mathrm{kg} \mathrm{BW}$ could improve metabolism and significantly impact the increase in the secretion of testosterone (Table-1). In addition, there was no significant increase or decrease in the $T_{3}$ and $T_{4}$ contents such that the $\mathrm{T}_{3} / \mathrm{T}_{4}$ ratio was stable.

The results showed no significant decrease in $\mathrm{T}_{4}$ followed by an increase in $T_{3}$ (Figure-2). The profile of $\mathrm{T}_{3}$ and $\mathrm{T}_{4}$ in the study was constant. This indicated no significant increase in the thyroid hormone or any change of $\mathrm{T}_{4}$ into $\mathrm{T}_{3}$ in response to an imbalance in physiological changes.

\section{$\mathrm{T}_{3} / \mathrm{T}_{4}$ ratio and $\mathrm{BW}$}

Metabolic abnormalities can be detected from the $\mathrm{T}_{3} / \mathrm{T}_{4}$ ratio. The results showed that the weekly $\mathrm{T}_{3} / \mathrm{T}_{4}$ ratio did not differ significantly (Table- 1 ). As is the case in mammals, the increase in the $\mathrm{T}_{3} / \mathrm{T}_{4}$ ratio in chickens would significantly affect the decrease in the secretion of other hormones. The decrease in estradiol was influenced by low $\mathrm{T}_{3}$ content. It was expected that this happened because of the decrease in the CYP19 mRNA gene expression in granulosa cells [23]. In addition, the BW of Pelung chickens significantly increased at each measurement. The BW of Pelung chickens continuously increased from day 14 to day 56, as summarized in Table-1 and illustrated in Figure-3.

\section{Frequency and duration of Pelung chicken sounds}

The experiment used 14-month-old chickens that could be classified as adult chickens. According to Asmara et al. [2], the duration of the crow of Pelung cocks aged more than 12 months was 6.30-12.80 s, its frequency was 4-67 Hz, and its intensity (volume) reached 45.20-65.20 dB. The administration of $A$. granosa shell powder for 56 days decreased the sound duration but not significantly. The duration of sound in the experiment was considered normal (Table- 2 and Figure-4).

The frequency of the crows of Pelung chickens in the experiment began to increase on days 14, 28, and 42 after the administration of the shell powder. The results of the experiment showed that there was a significant difference $(\mathrm{p}<0.05)$ in the frequency of the sound of Pelung chickens before treatment (days 0) with that after the administration of $A$. granosa shell powder (days 14, 28, 42), as shown in Table-2 and Figure-4.

\section{Testosterone hormone}

Testosterone values resulted from the conversion of OD using a standard curve with the formula $\mathrm{y}=-0.451 \ln (\mathrm{x})+1.4108$, as illustrated in Figure-5. As shown in Table-1 and Figure-6, there were significant differences $(\mathrm{p}<0.05)$ in testosterone levels after administering $A$. granosa shell powder. The testosterone content continuously increased on days 14, 28, 42, and 56 (after treatment). This indicated that the $\mathrm{Zn}$ content of the shell powder increased the testosterone level in Pelung chickens. 
Table-1: Data from the measurements of testosterone, $T_{3}, T_{4}$, and body weight of Pelung cocks.

\begin{tabular}{lccccc}
\hline Parameters & \multicolumn{3}{c}{ Average \pm SD, days } \\
\cline { 2 - 6 } & $\mathbf{0}$ & $\mathbf{1 4}$ & $\mathbf{2 8}$ & $\mathbf{4 2}$ & $\mathbf{5 6}$ \\
\hline Level of $\mathrm{T}_{3}(\mathrm{ng} / \mathrm{dL})$ & $0.50 \pm 0.46$ & $0.55 \pm 0.39$ & $0.42 \pm 0.36$ & $0.47 \pm 0.29$ & $0.46 \pm 0.30$ \\
Level of $\mathrm{T}_{4}(\mathrm{mcg} / \mathrm{mL})$ & $3.96 \pm 0.87$ & $3.21 \pm 1.29$ & $2.94 \pm 0.96$ & $3.29 \pm 1.65$ & $3.33 \pm 1.67$ \\
Ratio of $\mathrm{T}_{3} / \mathrm{T}_{4}$ & $0.13 \pm 0.08$ & $0.14 \pm 0.06$ & $0.16 \pm 0.16$ & $0.15 \pm 0.13$ & $0.18 \pm 0.16$ \\
Level of testosterone $(\mathrm{ng} / \mathrm{mL})$ & $0.13 \pm 0.06^{\mathrm{e}}$ & $0.35 \pm 0.04^{\mathrm{d}}$ & $1.10 \pm 0.05^{\mathrm{c}}$ & $1.27 \pm 0.04^{\mathrm{b}}$ & $1.42 \pm 0.06^{\mathrm{a}}$ \\
Body weight $(\mathrm{kg})$ & $2.70 \pm 0.14^{\mathrm{c}}$ & $3.75 \pm 0.54^{\mathrm{b}}$ & $3.82 \pm 0.55^{\mathrm{ab}}$ & $4.03 \pm 0.51^{\mathrm{ab}}$ & $4.52 \pm 0.40^{\mathrm{a}}$ \\
\hline
\end{tabular}

${ }^{a-e}$ Different superscripts in the same row indicate significant differences $(p<0.05) . T_{3}=$ Triiodothyronine, $T_{4}=$ Thyroxine

Table-2: Data on the duration and frequency of Pelung chicken sounds during this experiment.

\begin{tabular}{lccccc}
\hline Sound & \multicolumn{5}{c}{ Days } \\
\cline { 2 - 6 } & $\mathbf{0}$ & $\mathbf{1 4}$ & $\mathbf{2 8}$ & $\mathbf{4 2}$ & $\mathbf{5 6}$ \\
\hline Duration(s) & & & & & \\
Average $\pm S D$ & $7.53 \pm 3.09$ & $5.77 \pm 3.00$ & $5.62 \pm 2.98$ & $5.16 \pm 2.95$ & $4.97 \pm 3.04$ \\
Max & 10.69 & 9.93 & 9.70 & 10.41 & 9.47 \\
$\quad$ Min & 3.27 & 3.11 & 2.92 & 3.09 & 2.88 \\
Frequency (Hz) & & & & $11.53 \pm 2.53^{\mathrm{a}}$ & $6.41 \pm 1.87^{\mathrm{b}}$ \\
Average $\pm S D$ & $5.74 \pm 1.79^{\mathrm{b}}$ & $12.48 \pm 1.38^{\mathrm{a}}$ & $10.91 \pm 1.95^{\mathrm{a}}$ & 14.63 & 8.71 \\
Max & 7.94 & 14.18 & 13.31 & 8.45 & 4.11 \\
Min & 3.53 & 10.78 & 8.51 & & \\
\hline
\end{tabular}

a,b Different superscripts in the same row indicate significant differences $(p<0.05)$

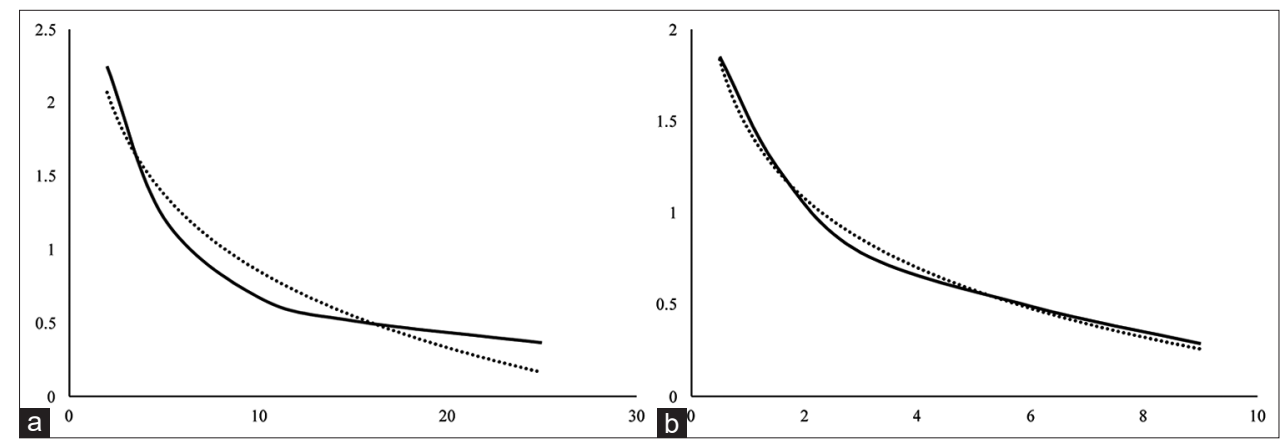

Figure-1: Standard curve of the hormones (a) triiodothyronine $T 3, R^{2}=0.9439$ and (b) thyroxine, $R^{2}=0.9955$.

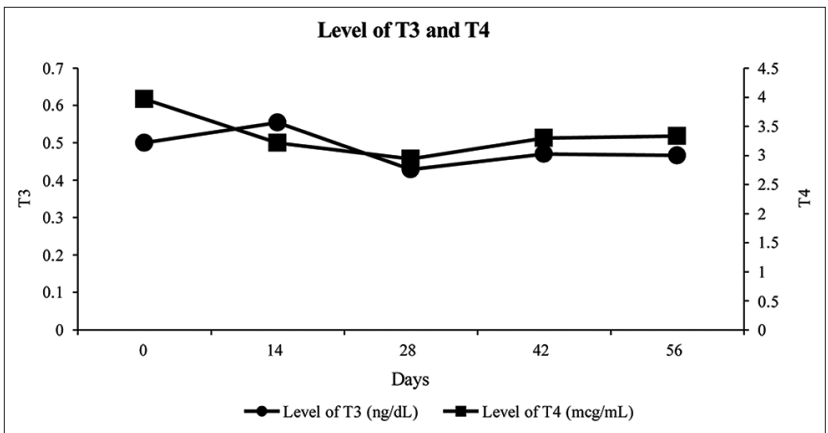

Figure-2: Triiodothyronine and thyroxine hormone levels in Pelung cocks before and after treatment (on the days $14,28,42$, and 56 ).

\section{Discussion}

\section{The effects of $A$. granosa shell powder on thyroid} hormones

The administration of $A$. granosa shell powder could improve metabolism. According to Cunningham and Klein [24], normal metabolism is indicated by the absence of a decrease in the levels of $\mathrm{T}_{4}$ hormone, which would significantly affect the increase in the $\mathrm{T}_{3}$ hormone. The decrease in the $\mathrm{T}_{4}$

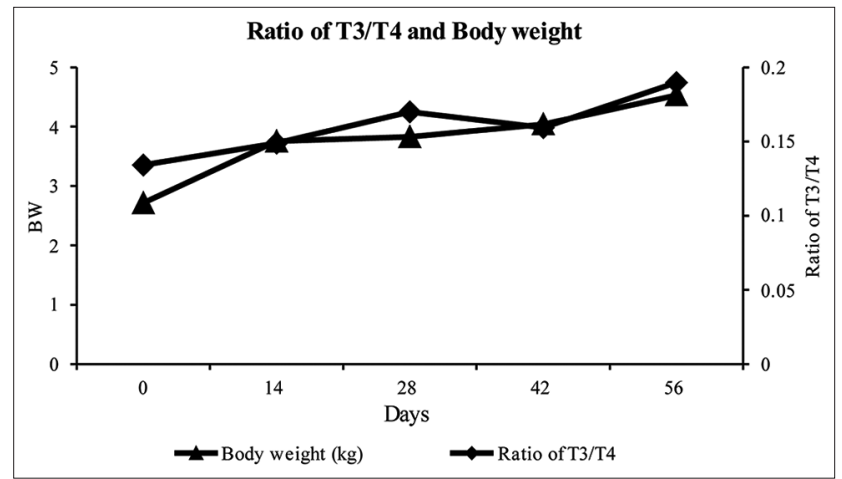

Figure-3: Triiodothyronine/thyroxine ratio and the body weight of Pelung chickens during treatment.

hormone indicates that there was a change in the $\mathrm{T}_{4}$ hormone into the $\mathrm{T}_{3}$ hormone. This might result from the increase in the conversion of $\mathrm{T}_{4}$ into $\mathrm{T}_{3}$ as an active hormone. The decrease in the $\mathrm{T}_{4}$ content is followed by an increase in $T_{3}$ content. $T_{3}$ was more active than the $\mathrm{T}_{4}$ hormone because the $\mathrm{T}_{4}$ hormone serves the function of a reserve before it is changed into $\mathrm{T}_{3}[25] . \mathrm{T}_{3}$ regulates the development and the physiological aspects at the cellular level, including 


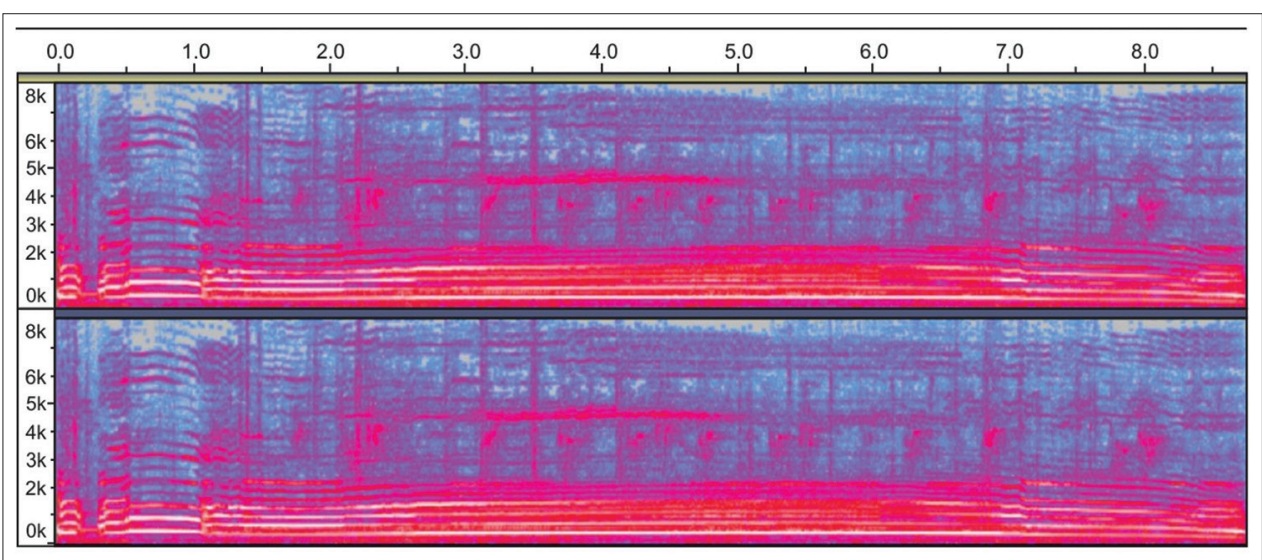

Figure-4: Pelung chicken crowing spectrogram.

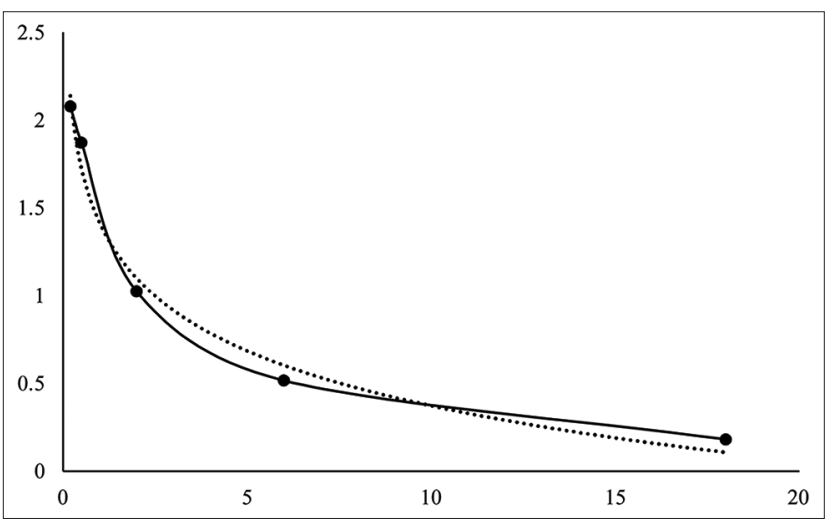

Figure-5: The standard curve of testosterone hormone, $R^{2}=0.9839$.

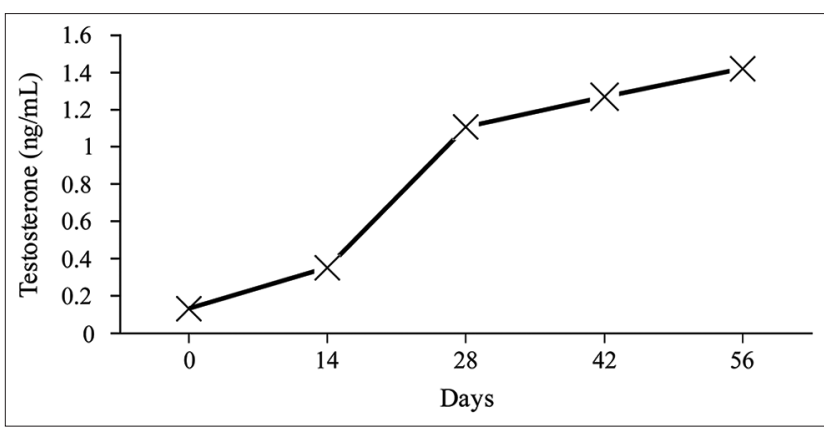

Figure-6: Testosterone content of Pelung chickens before (day 0 ) and after treatment (days 14, 28, 42, and 56).

metabolism, proliferation, differentiation, and cell apoptosis [23].

The administration of A. granosa shell powder indirectly increased the intake of $\mathrm{Zn}$. According to Kilic [8], low Zn levels occur with hypothyroidism, whereas a high $\mathrm{Zn}$ level is found with hyperthyroidism. The high concentration of $\mathrm{Zn}$ in the testes and accessory glands indicates that Zn plays an important role in the reproductive system [26]. This study showed that the administration of $A$. granosa shell powder, which contained $\mathrm{Zn}$, helped optimize hormones, especially testosterone. This was consistent with the results of Khalil [27] who indicated that the supplement of $\mathrm{Zn}$ could increase the production of eggs and improve the efficiency of the use of ransom.
According to Richards et al. [28], supplementation of $\mathrm{Zn}$ and $\mathrm{Cu}$ in chickens resulted in better stamina and health status of the digestive tract. The combination of $\mathrm{Zn}$ and Fe supported thyroid gland function [29].

\section{Effects of $A$. granosa shell powder on the $T_{3} / T_{4}$ ratio and $B W$}

The development of Pelung chickens is faster than that of other chickens [30]. It is indicated by the BWs of $2.11 \mathrm{~kg}$ cocks at 20 weeks of age, $2.5 \mathrm{~kg}$ at 42 weeks of age, and $4 \mathrm{~kg}$ adults [31]. This study showed that the BW of Pelung chickens increased at each measurement. The statistical analysis showed that $A$. granosa shell powder treatment caused an increase in BW of Pelung chickens on day 56 , and they were heavier than before the treatment. Compared to Pelung chickens with regular feed, the BW of Pelung chickens in this study was considered normal. It was assumed that the supplementation of $\mathrm{Zn}$ contained in the shell powder did not cause any physiological problems that could cause a decrease in the BW. According to Akhadiarto [32], the impact of the change in the feed formulation on the productivity of chickens could be observed in the existing production standard of chicken breeding, including BW, feed consumption, BW gain, and feed conversion. Iskandar and Susanti [31] suggested that if metabolism was good, it would increase BW, neck length, body length, beak width, the width of the fleshy part of the tail, and the position of the larynx from the lower jaw, which should be positively correlated to crow volume. In addition, the width of the neck muscle at the larynx, width of the neck muscle, and BW are positively correlated to the typical crow of Pelung chickens.

\section{Effects of $A$. granosa shell powder on the frequency} and duration of sounds

Pelung chickens have different individual characteristics. A decrease in sound duration (sound quality) of Pelung chicken crow, although still within the normal range and not significantly different, might have been caused by the raising system during treatment. These findings are similar to those of Rusfidra [33], where Pelung chicken cooping system could be one of the causal factors of a decrease in sound quality. There 
were two causal factors of the decrease in the quality of the crow of Pelung cocks. First, the cocks were not allowed to mate, and second, it is thought that the presence of elder male cocks is important for mating [33]. There are probably other factors that influence sound duration, including internal (genetic) and external (nutrition and environmental) factors [34]. The profile of sound of Pelung chicken at 12 months of age or less, on average, has a total duration of 8.85 $\mathrm{s}$, and the profile of the crow of Pelung chicken at 12 months of age or more has an average duration of $9.00 \mathrm{~s}$ [2]. Asmara et al. [3] suggested that the duration of the crow of Pelung chickens was in the range of $5.17-12.33 \mathrm{~s}$.

The increase in sound frequency was probably caused by the administration of $A$. granosa shell powder as a natural aromatase blocker, which could block the aromatase enzyme, thereby increasing the levels of testosterone. Testosterone is an underlying factor for crowing and social dominance $[35,36]$. The chirp of the male birds is controlled by testosterone produced in both the Leydig cells and the brain [37]. These findings are similar to those of Astuti et al. [20] who showed that aromatase blockers could increase the male canary song frequency.

\section{Effects of $A$. granosa shell powder on testosterone levels}

The $\mathrm{Zn}$ content of the powder could play an important role as an aromatase blocker, which can change testosterone into estrogen $[14,38,39]$. According to Park et al. [40], Zn represented an important nutrient in animal metabolism. Akram et al. [41] stated that $\mathrm{Zn}$ is an important nutrient because it is involved in various metabolic pathways. $\mathrm{Zn}$ in birds serves as an important nutrient and can be a food supplement to manipulate the chicken reproductive system. Omu et al. [19] showed that a Zn deficiency could result in a change in the function and weight of the testes because it could cause $40-70 \%$ decrease in germ cells in the total volume of the testes. $\mathrm{Zn}$ plays an important role in the reproductive organs. If $\mathrm{Zn}$ deficiency occurred, atrophy of seminiferous tubules and spermatogenesis disorder would follow [26]. Some studies showed that the increase in the testosterone content was consistent with good quality voice, strong muscles, and good comb growth [8,42-44]. In addition, the increase in testosterone was also consistent with the reproduction capability, as indicated by mating success [45].

It has been shown that the $\mathrm{Zn}$ content of $\mathrm{A}$. granosa shell powder can increase the reproductive performance of Pelung chicken through the increase in testosterone. Zn plays an important role in the function of more than 300 enzymes. Some enzymes in the body depend on Zn availability, such as RNA polymerase, alcohol dehydrogenase, and carbonic anhydrase. In addition, alkaline phosphatase depends on $\mathrm{Zn}$ as a cofactor. $\mathrm{Zn}$ also plays an important role in forming active biological molecular structures, such as $\mathrm{Cu}-\mathrm{Zn}$ dismutase, and influences apoptosis protein kinase $\mathrm{C}$ activities [19]. $\mathrm{Zn}$ is necessary for the growth and maintenance of body physiology in birds, including bone and feather growth, enzymes, and appetite regulation $[40,46]$. Optimal development requires a $\mathrm{Zn}$ percentage of approximately 0.0012 $0.0018 \%$ [47]. The high concentration of $\mathrm{Zn}$ in the testes and accessory glands indicated that $\mathrm{Zn}$ plays an important role in the reproductive organs. A Zn deficiency could result in hypogonadism. Therefore, it can be concluded that there is a positive correlation between $\mathrm{Zn}$ and testosterone $[19,26]$. A deficiency in $\mathrm{Zn}$ during the development of the testes could affect testicular steroidogenesis. Omu et al. [19] showed that a decrease in testosterone content was observed in the group with $\mathrm{Zn}$ deficiency, which caused the apoptosis of Leydig cells. It has been shown that $\mathrm{Zn}$ is involved in the regulation of testosterone production. Testosterone is produced by Leydig cells, and it is an important hormone in spermatogenesis. Therefore, a deficiency of $\mathrm{Zn}$ could be related to cell apoptosis at the early stage of spermatogenesis and spermatocyte, which could cause hypogonadism.

A. granosa shell powder administration in adult chickens has been proven to increase testosterone and sound frequency, but it could not increase duration. Thus, it can be concluded that the administration of $A$. granosa shell powder would not improve the quality of the crow in the cocks that have already developed a good quality crow.

\section{Conclusion}

The administration of $0.9 \mathrm{mg} / \mathrm{kg} \mathrm{BW}$ A. granosa shell powder could improve the metabolism, testosterone level, BW, and sound frequency of Pelung chickens.

\section{Authors' Contributions}

PA, CMA, HTSS, and RFY planned the study and designed the experiment. The study was managed and supervised by PA and CMA. PA, CMA, and RFY recorded and analyzed samples. CMA and RFY drafted the manuscript. RFY revised the manuscript under the supervision of PA, CMA, and HTSS. All authors read and approved the final manuscript.

\section{Acknowledgments}

We express our gratitude for the doctoral research grant from the Faculty of Veterinary Medicine, Universitas Gadjah Mada, Indonesia, for funding (Grant no.1707/UN1/FKH/HK4/2020).

\section{Competing Interests}

The authors declare that they have no competing interests.

\section{Publisher's Note}

Veterinary World remains neutral with regard to jurisdictional claims in published institutional affiliation. 


\section{References}

1. Ministry of Agriculture. (2011) Keputusan Menteri Pertanian Nomor 2918/kpts/OT.140/6/2011 Tentang Penetapan Rumpun Ayam Pelung. Ministry of Agriculture of the Republic of Indonesia, Jakarta, Indonesia.

2. Asmara, I.Y., Garnida, D. and Partasasmita, R. (2020) Crowing characteristics of Pelung chickens at different age and body weight. Biodivers. J. Biol. Divers., 2(9): 4339-4344.

3. Asmara, I.Y., Garnida, D. and Partasasmita, R. (2020) Short communication: Duration and volume of crowing of Pelung chickens of West Java, Indonesia. Biodivers. J. Biol. Divers., 21(2): 748-752.

4. Josiak, K., Jankowska, E.A., Piepoli, M.F., Banasiak, W. and Ponikowski, P. (2014) Skeletal myopathy in patients with chronic heart failure: Significance of anabolic-androgenic hormones. J. Cachexia Sarcopenia Muscle, 5(4): 287-296.

5. Çınar, V., Talaghir, L.G., Akbulut, T., Turgut, M. and Sarkkaya, M. (2017) The effects of the zinc supplementation and weight trainings on the testosterone levels. Hum. Sport Med., 17(4): 58-63.

6. Sopian, Y., Darwati, S. and Sumantri, C. (2014) Performance $\mathrm{F} 1$ of sentul $\mathrm{x}$ kampung and pelung $\mathrm{x}$ sentul from 0 to 12 weeks age J. Anim. Prod. Sci. Technol., 3(3): 131-137.

7. Mullur, R., Liu, Y.Y. and Brent, G.A. (2014) Thyroid hormone regulation of metabolism. Physiol. Rev., 94(2): 355-382.

8. Kilic, M. (2007) Effect of fatiguing bicycle exercise on thyroid hormone and testosterone levels in sedentary males supplemented with oral zinc. Neuroendocrinol. Lett., 28(5): 681-685.

9. Dittrich, F., Ramenda, C., Grillitsch, D., Frankl-Vilches, C., Ko, M.C., Hertel, M., Goymann, W., Maat, A.T. and Gahr, M. (2014) Regulatory mechanisms of testosterone-stimulated song in the sensorimotor nucleus HVC of female songbirds. BMC Neurosci., 15(1): 1-16.

10. Pomara, C., Barone, R., Marino Gammazza, A., Sangiorgi, C., Barone, F., Pitruzzella, A., Locorontondo, N., Gaudio, F.D., Salerno, M., Maglietta, F.,Sarni, A.L., Felice, V.D., Cappello, F. and Turillazzi, E. (2016) Effects of nandrolone stimulation on testosterone biosynthesis in leydig cells. J. Cell. Physiol., 231(6): 1385-1391.

11. Ali, E.A., Zhandi, M., Towhidi, A., Zaghari, M., Ansari, M., Najafi, M. and Deldar, H. (2017) Letrozole, an aromatase inhibitor, reduces post-peak age-related regression of rooster reproductive performance. Anim. Reprod. Sci., 183(5): 110-117.

12. Golini, J. (2015) Rodent and human trials of the testosterone modulating experimental nutraceutical taxadrol. J. Biosens. Bioelectron., 6(3): 6-9.

13. Mohamad, S.F.S., Mohamad, S. and Jemaat, Z. (2016) Study of calcinations condition on decomposition of calcium carbonate in waste cockle shell to calcium oxide using thermal gravimetric analysis. ARPN J. Eng. Appl. Sci., 11(16): 9917-9921.

14. Astuti, P., Airin, C.M., Sarmin, S., Nururrozi, A. and Harimurti, S. (2019) Effect of shell as natural testosterone boosters in Sprague Dawley rats. Vet. World, 12(10): 1677-1681.

15. Nurjanah, N., Abdullah, A., Hidayat, T. and Yulianti, I. (2015) Characteristics of minerals and Vitamin B12 by tiger snails, shellfish snow, Meretrix meretrix. Agric. Biol. Sci. J., 1(5): 186-189.

16. Sahin, K., Orhan, C., Tuzcu, M., Sahin, N., Sylla, S., Ojalvo, S.P. and Komorowski, J. (2019) The effect of magnesium, zinc, and selenium, used alone or in combination, on strength and anabolic hormone levels in rats. FASEB J., 33(1): 839-847.

17. Astuti, P., Airin, C.M., Nururrozi, A. and Harimurti, S (2018) Oyster Shell Powder as Alternatives Macromineral for Synthetic Testosterone. Proceedings of the $20^{\text {th }}$ FAVA Congress and $15^{\text {th }}$ KIVNAS PDHI, Bali, Indonesia. p164-165.

18. Sankako, M.K., Garcia, P.C., Piffer, R.C., Dallaqua, B., Damasceno, D.C. and Pereira, O.C.M. (2012) Possible mechanism by which zinc protects the testicular function of rats exposed to cigarette smoke. Pharmacol. Rep., 64(6): 1537-1546.

19. Omu, A.E., Al-Azemi, M.K., Al-Maghrebi, M., Mathew, C.T., Omu, F.E., Kehinde, E.O., Anim, J.T., Oriowo, M.A. and Memon, A. (2015) Molecular basis for the effects of zinc deficiency on spermatogenesis: An experimental study in the Sprague-Dawley rat model. Indian $J$. Urol., 31(1): 57-64.

20. Astuti, P., Airin, C.M., Nurrurozi, A., Aidi, R., Hana, A., Hadi, S. and Harimurti, H. (2020) Potential Natural Aromatase Blockers on Enhance the Frequency and Sound Quality of Male Canaries. E3S Web of Conferences. p1-3.

21. Chaudhary, S.K., Mandal, A.B., Bhar, R., Gopi, M., Kannan, A., Jadhav, S.E. and Rokade, J.J. (2019) Effect of graded levels of soapnut (Sapindus mukorossi) shell powder on reproductive performance in broiler breeders. Asian Australas. J. Anim. Sci., 32(1): 118-125.

22. Yuneldi, R.F., Saraswati, T.R. and Yuniwarti, E.Y.W. (2018) Profile of SGPT and SGOT on male rats (Rattus norvegicus) hyperglycemic after giving Insulin leaf extract (Tithonia diversifolia). Biosaintifika J. Biol. Biol. Educ., 10(3): 519-525.

23. Sukandar, P.B., Soejono, S.K. and Utoro, T. (2013) Cytochrome P450 aromatase (CYP19) gene expression in ovarian granulose cells of hypothyroid rats induced by propylthiouracil. J. Med. Sci., 45(3): 112-119.

24. Cunningham, J.G. and Klein, B.G. (2007) Veterinary Physiology. Michigan State University, USA.

25. Astuti, P., Kusumawati, A., Airin, C.M., Maheshwari, H. and Sjahfirdi, L. (2010) Physiological response of Bligon buck to transportation: Relation to level of thyroid hormone. J. Vet., 11(2): 87-91

26. Kaya, O., Gokdemir, K., Kilic, M. and Baltaci, A.K. (2006) Zinc supplementation in rats subjected to acute swimming exercise: Its effect on testosterone levels and relation with lactate. Neuroendocrinol. Lett., 27(1-2): 267-270.

27. Khalil, K. (2010) The use of local mineral formula for laying hens. Med. Anim. Husbandry, 33(2): 115-123.

28. Richards, J., Hampton, T., Wuelling, C., Wehmeyer, M., Parker, D. and Dibner, J. (2005) MINTREX ${ }^{\mathrm{TM}} \mathrm{Zn}$ and MINTREX $^{\mathrm{TM}} \mathrm{Cu}$ Organic Trace Minerals Improve Intestinal Strength and Immune Response to Coccidiosis Infection and/or Vaccination in Broilers. Proceedings of the $15^{\text {th }}$ European Symposium on Poultry Nutrition, Balatonfured, Hungary. p257-259.

29. Rizzi, L., Bargellini, A., Borella, P. and Mordenti, A. (2005) The role of selenium and iodine in controlling some egg minerals. Ital. J. Anim. Sci., 4(2): 504-506.

30. Nataamijaya, A.G. (2010) Potential development of local chicken to support improvement farmers welfare. J. Agric Res. Dev., 29(4): 131-138.

31. Iskandar, S. and Susanti, T. (2007) The characteristic and the use of Pelung chicken in Indonesia. Wartazoa, 17(3): 128-135.

32. Akhadiarto, S. (2017) Study of local feed production feed factory compared to performance of the local chicken in Gorontalo. J. Ind. Technol. Assess., 11(1): 41-50.

33. Rusfidra, A. (2006) Development of Bioacoustic Besearch in Indonesia: A Study on the Balenggek Crow, Pelung Chicken and Bekisar Chicken. National Conference of MIPA, Yogyakarta, Indonesia. p352-372.

34. Daryono, B.S., Mushlih, M. and Perdamaian, A.B.I. (2020) Vocalizaon characters and forkhead box p2 (foxp2) polymorphism in Indonesian crowing-type chicken (Gallus gallus domesticus). Iran. J. Appl. Anim. Sci., 10(1): 131-140.

35. Queiroz, S.A. and Cromberg, V.U. (2006) Aggressive 
behavior in the genus Gallus sp. Braz. J. Poult. Sci., 8(1): 1-14.

36. Favati, A., Leimar, O., Radesäter, T. and Løvlie, H. (2013) Social status and personality: Stability in social state can promote consistency of behavioural responses. Proc. Biol. Sci., 281(1774): 20132531.

37. Alward, B.A., Cornil, C.A., Balthazart, J. and Ball, G.F. (2018) The regulation of birdsong by testosterone: Multiple time-scales and multiple sites of action. Horm. Behav., 104(8): 32-40

38. Yuneldi, R.F., Airin, C.M., Saragih, H.T.S. and Astuti, P. (2021) Application of natural aromatase blocker towards the level of testosterone in rooster layer [Gallus gallus gallus (Linn., 1758)]. In: Key Engineering Materials. Trans Tech Publication Ltd., Switzerland. p251-255.

39. Yuneldi, R.F., Airin, C.M., Saragih, H.T.S. and Astuti, P. (2021) Profile of Thyroid in Male Layer Chickens Given by Testosterone. In: IOP Conference Series: Earth and Environmental Science. p1-5.

40. Park, S., Nisbet, D.J. and Ricke, S. (2004) Review on the role of dietary zinc in poultry nutrition, immunity, and reproduction. Biol. Trace Elem. Res., 101(2): 147-163.

41. Akram, Z., Fatima, M., Shah, S.Z.H., Afzal, M. Hussain, S.M., Hussain, M., Khan, Z.I. and Akram, K. (2019) Dietary zinc requirement of Labeo rohita juveniles fed practical diets. J. Appl. Anim. Res., 47(1): 223-229.
42. Alward, B.A., Balthazart, J. and Ball, G.F. (2017) Dissociable effects on birdsong of androgen signaling in cortex-like brain regions of canaries. J. Neurosci., 37(36): 8612-8624

43. Sato, K., Iemitsu, M., Matsutani, K., Kurihara, T., Hamaoka, T. and Fujita, S. (2014) Resistance training restores muscle sex steroid hormone steroidogenesis in older men. FASEB J., 28(4): 1891-1897.

44. Otoo, L., Koffuor, G., Ansah, C., Mensah, K., Benneh, C. and Ben, I. (2015) Assessment of an ethanolic seed extract of Picralima nitida ((Stapf) Th. and H. Durand) on reproductive hormones and its safety for use. J. Intercult. Ethnopharmacol., 4(4): 293-301.

45. Garamszegi, L.Z., Eens, M., Hurtrez-Boussès, S. and Møller, A.P. (2005) Testosterone, testes size, and mating success in birds: A comparative study. Horm. Behav., 47(4): 389-409.

46. Naz, S., Idris, M., Khalique, M.A., Ur-Rahman, Z., Alhidary, I.A., Abdelrahman, M.M., Khan, R.U. Chand, N. Farooq, U. and Ahmad, S. (2016) The activity and use of zinc in poultry diets. Worlds Poult. Sci. J., 72(1): 159-167.

47. Batal, A.B., Parr, T.M. and Baker, D.H. (2001) Zinc bioavailability in tetrabasic zinc chloride and the dietary zinc requirement of young chicks fed a soy concentrate diet. Poult. Sci., 80(1): 87-90.

\section{$* * * * * * * *$}

